\title{
Çocuk Gelişimi Öğrencilerinin Ait Olma Düzeyleri İle Yetişkin Motivasyonları Arasındaki İlişkinin İncelenmesi
}

$\ddot{\mathbf{O} z}$

\author{
Esin SEZGIN* \\ Erhan ALABAY ${ }^{\dagger}$
}

Bu çalışmanın amacı, çocuk gelişimi lisans öğrencilerinin ait olma düzeyleri ile yetişkin motivasyonları arasındaki ilişkinin incelenmesidir. Araştırmada nicel araştırma desenlerinden, ilişkisel tarama modeli tercih edilmiştir. Araştırmanın çalışma grubunu, İstanbul'da eğitim veren üniversitelerden rastgele örnekleme yöntemine göre seçilmiş toplam 166 çocuk gelişimi lisans öğrencisi oluşturmaktadır. Araştırmada veri toplama aracı olarak "Ait Olma Ölçeğì" ile "Yetişkin Motivasyonları Ölç̧eğì" kullanılmıştır. Araştırma sonucunda çocuk gelişimi lisans öğrencilerinin sınıf düzeyleri ile Ait Olma Ölçeği ve Yetişkin Motivasyonları Ölçeği puanları arasında anlamlı bir farklılaşmaya rastlanmazken, cinsiyet değişkeni arasında anlamlı bir farklılaşmaya rastlanmışıı. Bu farklılaşmanın kadın lisans öğrencilerin lehine olduğu sonucuna ulaşılmıştır. Ayrıca çocuk gelişimi lisans öğrencilerinin Ait Olma Ölçeği "Arkadaş Grubu", "Aile" ve "Meslek" alt boyut puanları ile Yetişkin Motivasyonları Ölçeği "İçsel Motivasyon", "Dışsal Motivasyon" ve "Toplam Motivasyon" puanları arasında pozitif yönlü orta düzeyde anlamlıbir ilişkinin olduğu sonucuna varılmıştır.

Anahtar Kelimeler: Çocuk Gelişimi Lisans Öğrencisi, Ait Olma Düzeyi, Yetişkin Motivasyonları.

\section{Investigation of the Relationship between Child Development Students' Belonging Levels and Adult Motivations}

\begin{abstract}
The aim of this study is to examine the relationship between child development university students' belonging levels and adult motivations. The research was designed according to the relational survey model, one of the quantitative research designs. The study group of the study consists of 166 child development undergraduate students selected by random sampling method from universities in Istanbul. The "Belonging Scale" and the "Adult Motivations Scale" were used as data collection tools in the study. As a result of the research, no significant difference was found between the grade levels of the students and the scores of the Belonging Scale and Adult Motivations Scale. However, a significant difference was found between students' gender variable and scale scores. It is concluded that this differentiation is in favor of female undergraduate students. In addition, a moderate positive correlation was found between the scores of "Friendship Group", "Family" and "Profession" and "Intrinsic Motivation", "Extrinsic Motivation" and "Total Motivation" scores.
\end{abstract}

Keywords: Child Development Undergraduate Student, Level of Belonging, Adult Motivations.

Geliş/Received: 18.10 .2020

Kabul/Accepted: 17.02.2021

* Bu çalışma için, Sağlık Bilimleri Üniversitesi Hamidiye Bilimsel Araştırmalar Etik Kurulu'na başvurulmuş olup, 02.10.2020 tarih, 2020/19 toplantı sayısı ve 20/375 kayıt numarası ile etik kurul alınmıştır. Ayrıca araştırmanın her bir basamağında tüm yayın etiklerine uyulmuştur.

\footnotetext{
* Dr. Öğr. Üyesi, Sağlık Bilimleri Üniversitesi, Hamidiye Sağlık Bilimleri Fakültesi, Çocuk Gelişimi Bölümü, esin.sezgin@sbu.edu.tr, Orcid: 0000-0002-9772-9855

${ }^{\dagger}$ Doç. Dr. Sağlık Bilimleri Üniversitesi, Hamidiye Sağlık Bilimleri Fakültesi, Çocuk Gelişimi Bölümü, erhan.alabay@sbu.edu.tr, Orcid: 0000-0003-4025-2352

(Makale türü: Araştırma makalesi)
} 


\section{Giriş}

Üniversite eğitiminin hem toplumsal hem de bireysel etkileri büyüktür. Kaliteli bir eğitim sürecinden geçen lisans öğrencileri elde ettiği akademik bilgiler doğrultunda özel ve sosyal getiriler elde edebilir. Öğrenciler mezun olduktan sonra istihdam olasılığının artması, verimlilik ve daha fazla gelir elde etme gibi firsatlara sahip olabilmektedir (Gölpek, 2012). Fakat her üniversite öğrencisi üniversite eğitimini tamamlayamamaktadır. Çeşitli nedenlerden dolayı öğrencilerin üniversite eğitimini yarıda bırakmak zorunda kaldığı görülmektedir. Şimşek (2012)'in çalışmasına göre üniversite öğrencilerinin fakülte öğretim elemanlarından memnun olmama, sosyal etkinliklerden memnun olmama ve fakültedeki derslerde zorlanma gibi nedenlerinden dolayı üniversiteyi bıraktığı saptanmıştır. Türkiye'deki resmi verilere göre, 2013-2014 eğitim öğretim döneminde 135 bin, 2014-2015 eğitim öğretim yıllnda 161 bin öğrenci kayıt sildirmiştir. 2015-2016 eğitim öğretim yılında ise bu sayı 197 bine çıkmıştır. Sonraki yıllara gidildikçe bu sayının daha da arttığı görülmüştür. 2017-2018 eğitim öğretim yılında üniversiteyi bırakanların sayısı bir önceki yıla oranla \%92 artarak 408 bine yükselmiştir (Güçlü, 2019). Üniversitede lisans programına devam eden öğrencilerin ait olma duygusu ve motivasyon ile akademik başarı, cinsiyet, sınıf düzeyi arasındaki ilişkiyi inceleyen birçok çalışma olduğu görülmektedir. Yapılan bu çalışmalarda, aidiyet duygusu ve motivasyonun özellikle eğitim ortamlarında akademik başarıyı, üniversite tercihini, üniversiteye devamını etkilediği bulunmuştur. Öğrencilerin okul kapsamında öğrenme yöntemleri ve gelişimleri, akademik olarak başarılı olabilmelerini sağlamak için bilgi ve bilişsel kaynakları geliştirme gibi temel konularla ilgilenen araştırmacılar, öğrenci motivasyonu olumlu yönde etkileyecek, yeni öğretim müdahaleleri, projeler, yeni müfredat ve yenilikçi teknolojik araçlar geliştirmeye çalışmışlardır (Pintrich, 2003).

Türkiye'deki üniversite öğrencilerinin eğitim kurumlarına devam etmelerine ve üniversite ve bölüm seçimine, öğrenmeye motivasyon ve ait olma duygusunun etkilerinin olduğu düşünülmektedir. Çocuk gelişimi lisans öğrencilerinin motivasyon ve ait olma duygularının karşılaştırıldığı ilk çalışma olma özelliğini taşıyan bu çalışma, üniversite çocuk gelişimi lisans programına devam eden öğrencilerinin motivasyon ve ait olma duygularının cinsiyet, sınıf düzeyi ile ilişkilerini incelemeyi amaçlamaktadır. Elde edilen veriler doğrultusunda daha etkili eğitim program ve yöntemlerinin tasarlanmasına, daha yüksek eğitim performansına katkıda bulunulmasında ve çocuk gelişimi lisans öğrencilerinin içsel ve dışsal motivasyon ve aile arkadaş ve mesleğe ait olma düzeyleri belirlenerek üniversite eğitimine devam etme, akademik başarı ve mesleklerine yönelik olumlu algı geliştirmelerinde de yapılacak olan çalışmalara 1şık tutacağı düşünülmektedir. 


\section{Ait Olma Duygusu}

İnsanların diğer insanlarla yakın, kalıcı ve olumlu ilişkiler kurma, bir gruba ait olma ve ait olduğu gruplarla bağlarını koruma gibi ihtiyaçlar insan davranışının temel ihtiyaçları olarak görülmektedir. $\mathrm{Bu}$ ihtiyaçlar içinde diğer insanlarla sürdürülebilir ilişkiler kurma ve sürdürme motivasyonu ise aidiyet ihtiyacı olarak adlandırılmaktadır. Aidiyet ihtiyacını oluşturan kişilerarası ilişkiler, insan evriminin başlangıcından itibaren yaşamın içinde var olmaya devam etmektedir. Bireylerle güçlü sosyal bağlara sahip olmak, insanların hem hayatta kalma hem de üreme şansını artırmıştır. Bu nedenle ortaya çıkan doğal seleksiyon, bu tür bağlar için güçlü bir motivasyona sahip ataları tercih etmiş ve bireylerin kabul görmelerini ve reddedilmelerini önleyen özelliklerin gelişmesine neden olmuştur (DeWall, Deckman, Pond, ve Bonser, 2011; Silvia ve Kwapil, 2011; Spithoven, Lodder, Goossens, Bijttebier, Bastin, Verhagen, ve Scholte, 2017; Aydın, Şahin, Yavuz Güzel, Abayhan, Kaya ve Ceylan, 2013).

Alanyazın incelendiğinde, birçok kuramcının kuramına göre ait olma, kişiler için temel ihtiyaçlar arasında sayılmaktadır (Ersanlı ve Koçyiğit, 2013). Adler, bireyin ruh sağlığı ve toplum sağlığının ait olma duygusu ile ilişkili olduğunu, ait olmaya yönelik çabalarında aşağılık duygularının üstesinden gelmek için doğuştan gelen yaratıcılığa sahip olduğunu savunmuştur (Shifron, 2010).Maslow (1987)'a göre fizyolojik ve güvenlik ihtiyacı karşılandıktan sonra insanın en önemli ihtiyaçlarından birkaçı da statü, bağl1lık ve yüksek benliktir (Kuşat, 2003; Ersanlı ve Koçyiğit, 2013). Ait olmanın içeriğinde insanlar arasında diğer insanlar tarafından kabul edilmesi, bilinip tanınması, bulunduğu ortamda değerli hissedilmesi ve değerli görülmesi gibi durumlar bulunmakta ve bu durumlarbireyler için oldukça önem arz etmektedir (Levett-Jones, Lathlean, Maguire ve McMillan, 2011). Fromm ise ilişki ihtiyacı ve köklülük ihtiyacı bireyin bir köke ait olmayı içerdiğinden bahsetmektedir (Ersanlı ve Koçyiğit, 2013).

Ait olma ihtiyacı genellikle bireyler ve topluluklar için doğuştan gelen, temel ve güçlü bir toplumsal ihtiyaçtır (Wilson, 2014). Aidiyet ise "bireyin çevresi ile kurduğu ve aile, vatan, etnik köken gibi bilinçsiz ya da eğitim, siyaset, meslek gibi bilinçli tercihleri ile şekillendirdiği güncellenen ve değişkenlik içeren (Keskin ve Pakdemirli, 2016), güven ihtiyacını karşılamaya dönük bir güç ortakllğında ait olan ve ait olunan arasındaki karşıllkkl sorumluluğu harekete geçiren (Alptekin, 2011) bir durum" olarak tanımlanabilir. Ait olma duygusu, onlarca yıldır hem eğitim alanında hem de psikoloji alanlarında sıklıkla kullanılan bir kavramdır. Genel anlamda, ait olma duygusu, başkalarıyla bir ilişki veya bağlantı hissini ifade eder (Booker, 2006). Ait olma duygusu, "gruba ait olma, birbirleri için önemli olma, paylaşılmış ortak bir amaç ve birliktelik" olarak ele alınabilir (Keskin ve Seferoğlu, 2017). Ait olma kavramı ile bağl1lık kavramı karşılaştırıldığında ise ait olma durumunun daha köklü ve çift yönlü olduğunu söylememiz mümkündür. Bağlılık tek taraflılık içerirken, aidiyet ise tarafların karşılıklı 
kabul ve sahiplenmesi sonucunda bireyin hem kişisel ve sosyal kimliğinin yansıması olarak ele alınır (Keskin ve Pakdemirli, 2016).

Bireyin yaşamının anlam bulması ve yaşamının desteklenmesi için en önemli unsurlardan birisi de bireyin ailesine, mesleğine, kültürüne ve içinde bulunduğu topluma aidiyet duygusudur. (Mavili, Kesen ve Daşbaş, 2014). Alanda bu konu ile ilgili yapılan çalışma bulguları incelendiğinde, aidiyet duygusu yüksek olan bireylerin işlevsellik düzeylerinin de yükseldiği tespit edilmiştir. Aynı zamanda yine kişinin aidiyet duygusu arttıkça bireyin hem psikolojik hem de sosyal işlevsellik özelliklerinin de pozitif yönde etkilendiği saptanmıştır (Hagerty, Williams, Coyne ve Early, 1996). Birey aidiyet duygusunu kaybettiğinde ise yeniden bağlanma ya da ait olma şansı olmadığına dair bir algıya sahip olur ve birey kendini güveli hissetmez. Bunun sonucunda, birey sosyal soyutlanma, yalnızlık ve yabancılaşma gibi durumları yaşayabilir ve bu durumun sonucunda saldırgan, antisosyal ve dürtüsel davranışlar gösterebilir. Çalışmalar, bu bireylerde şizofreni, suç veya öç alıcı davranışı içeren durumlar görülebildiği (Ferguson, 2010; Wilson, 2014), yüksek düzeyde aidiyet ihtiyacının, düşük benlik saygıs1, yalnızlık, olumsuz etki ve nevrotiklik ve eleştirilme veya reddedilme korkusu gibi çeşitli sorunlu veya istenmeyen özelliklerle ilişkili olduğu sonucuna ulaşılmıştır (Leary, Kelly, Cottrell ve Schreindorfer, 2013). Ayrıca araştırmacılar, yalnızlık, kaygı veya depresyon durumu ile baş eden bireylerin problemlerinden kurtulmaları için yakını bireyler tarafından sevgi, ilgi ve kabul görme gibi duyguların önemi üzerine durmuşlardır (Wilson, 2014).

\section{Motivasyon}

Davranışı açıklamada kullanılan bir terim olan motivasyon, insanların davranışları, istekleri ve ihtiyaçlarını içermektedir (Şeker, 2015). Motivasyon genel anlamda, "kişide davranışın uyarılmasını ilk istek ve arzuların seçilmesi, sıralanması, yönlendirilmesi ve sürdürülmesi yoluyla bilişsel ve motor süreçleri başlatan, yönlendiren, koordine eden, güçlendiren, sonlandıran ve değerlendiren dinamik bir uyarılma halidir”. Bireyin davranışına enerji vermekte ve hedefe ulaşmak için harekete geçmeye zorlamaktadır (Singh ve Singh, 2011; Dörnyei ve Ushioda, 2011). Motivasyon genellikle içsel ve dişsal motivasyon olmak üzere iki boyutta ele alınmaktadır. İçsel motivasyon daha çok eğlenceli ve ilginç şeyleri yapmayı ifade eder (Fagan, Neill ve Wooldridge, 2008; Pintrich ve Schunk, 2002). Bireyin seçtiklerine inancı fazla ise kendi iyiliği için faaliyette bulunma artar ve faaliyetin bireyde oluşturduğu hedef ve beklentileri (Patall, Cooper ve Robinson, 2008), merak, ustalaşma arzusu, etkinliklerde yetkinlik gösterme nedeni ile hazır olmayı (Shroff, Vogel ve Coombes, 2008) içermektedir. Dışsal motivasyon daha çok ödül ve cezaya odaklanır, başkalarının onayı, bir faaliyetin bir amaç için meşgul olma aktivite ile özdeşleşme ve bütünleşme olarak ele almaktadır (Ryan ve Deci, 2000; Pintrich ve Schunk, 2002). 
Motivasyon özellikle öğrenmede çok önemli bir rol oynamaktadır (Singh, 2011). Öğrenmeye duyulan heyecan, ilgi ve coşku motivasyonun temel bileşenleridir (Aggarwal, 2015). Sadece öğrenme ile sonuçlanan faaliyeti harekete geçirmekle kalmaz, aynı zamanda sürdürür ve yönetir (Singh ve Singh, 2011; Singh, 2011). Öğrencilerin bilgi edinmelerini, sosyal nitelikler geliştirmelerini, inisiyatif almalarını, aktivitelere devam etmelerini, performanslarını daha iyiye ulaştırmalarını sağlamakta, davranışa yön ve amaç vermekte, araştırma ve disiplin duygusu geliştirmelerine yardımcı olmaktadır (Singh ve Singh, 2011; Aggarwal, 2015). Motivasyonu birçok farklı etmen etki etmektedir. Bazen öğrencinin kendi kişiliği motivasyonu etkileyeceği gibi bazen de öğrencinin yeteneği motivasyonu etkileyebilir. Bunun dışında bireyin kişilik özellikleri, öğretim sürecinde kullanılan materyal ve bu materyallerin özellikleri, eğitim ortamı, eğitim aldığı eğitimci özellikleri gibi farklı durumlarda öğrencinin motivasyonunu olumlu veya olumsuz olarak etkileyebilmektedir (Slavin, 2013). Ayrıca motivasyonun kültürden de etkilendiği görülmektedir. Örneğin, Hong Kong ve Çin'deki öğrencilerin öğrenme motivasyonu Konfüçyüsçü bir bakış açısıyla bağlantılıdır ve Batı kültüründen farklıdır. Çinli öğrenciler öğrenme, kişisel hırs, aile, akran desteği, maddi ödül ve ilgi dikkate alınarak daha pragmatiktir (Doghonadze, 2018).

Tüm eğitim basamaklarında olduğu gibi üniversite öğrencileri ile de motivasyon üzerine pek çok çalışma yapılmıştır. Bu araştırmalar sonucunda eğitim çerçevesinde motivasyonu artırmanın pek çok yolu olduğu sonucuna ulaşılmıştır. Bunların arasında, öğrencilerin yeteneklerine, yaratıcılıklarına, başarılarına yönelik güven ortamı yaratmak, benlik saygısını arttırmak, objektif, kullanılabilir, seçim yapabileceği, heyecan verici konular sunmak, ses-video materyalleri, iyi örnekler, interaktif ders verme, öğrencilerin eğitim sürecinin planlanmasına ve uygulamasına katılımını sağlamak, aktif öğrenme firsatı verme, öğrenme konusunda daha fazla sorumluluk alma, kendilerini gözlemleme ve öğrenme stili, yöntemleri ve stratejileri konusunda verimli olma, düzenli öz-değerlendirme, daha öz-eleştirel ve talep etme, bilgiye ulaşmak için çalışma vb. yer almaktadır (Doghonadze, 2018). Öğrenci motivasyonunun değiştirilebilir ve yukarıda belirtilen değer ve koşullara duyarlı olduğu düşünülmektedir. Bu durum öğretmenler ve okul psikologları tarafından öğretim yöntem ve tekniklerin, sınıf ve okul tasarımların, öğrencileri akademik başarı için motive etmede fark yaratabileceğini gösterir (Linnenbrink ve Pintrich, 2002).

Konu ile ilgili yapılan çalışmalar incelendiğinde motivasyon ve ait olmaya yönelik çalışmalara çok az sayıda olduğu görülmektedir. Araştırmamızla benzerlik gösteren ulaşabildiğimiz tek çalışma olarak, üniversiteye öğrenci olarak devam eden sporcuların başarı motivasyonu, algılanan okula ait olma ve akademik başarı arasındaki ilişkilerini karşılaştıran araştırma karşımıza çıkmaktadır (Anderson, 2010). Konu ile ilgili daha çok alanyazında üniversite öğrencilerinin motivasyonları veya ait olma duyguları ile yapılmış çalışmalar yer almaktadır. Aidiyet duygusuna yönelik yapılan çalışmalarda; 
öğrencilerin okula aidiyeti ve arkadaşlarına verdikleri değer arasındaki ilişki (Goodenow ve Grady, 2010), farklı okullara devam eden öğrencilerin ait olma duygusu (Xin, 2010), hemşirelik öğrencilerinin mesleki ait olma (Sedgwick ve Rougerau, 2010), okula ait olma, akademik duygular ve akademik başarı (Fong Lam, Chen, Zhang ve Liang, 2015), aidiyet duygusu zihinsel sağlık, refah ve yaşam kalitesi ile ilişkisi (Choenarom, Williams ve Hagerty, 2005; Young, Russell ve Powers, 2004), farklı kültürlerde üniversiteye ait olma duygusuna etki eden etmenler (Museus, Yi ve Saelua, 2017) incelenmiştir. Bir diğer çalışmada ise, okula ait olma duygusu ile üstbilişsel ve akademik zaman yönetimi stratejileri arasındaki ilişkilere aracılık etmiştir (Won, Wolters ve Mueller, 2017).

Önemli sayıda çalışmanın motivasyonu içsel ve dışsal motivasyon kategorilerini kullanarak değerlendirdiğini ve birçok çalışmanın öğrencilerin motivasyonunu veya motivasyon eksikliğini belirlemeye yönelik olduğu görülmektedir (Schoeffel, Wazlawick ve Ramos, 2018). Özellikle eğitimin tüm aşamalarına yönelik yapılan araştırmalarda motivasyonun önemli bir yer tuttuğu da görülmektedir. $\mathrm{Bu}$ araştırmalar incelendiğinde, öğrencilerin davranışsal, duygusal ve bilişsel katılımının öğrencilerin çalışma motivasyonunu belirlediği, bireyin akademik çalışmalarının içsel ve dışsal olarak motive olma derecelerine etkisinin olduğu (Henderson King ve Smith, 2006), motivasyon ve öğrenmeye yönelik odaklanma (Kiran Singh, 2012), motivasyon ve çaba düzeyini belirleyen karar verme süreci (Cole, Feild ve Harris, 2004), motivasyon ile akademik başarı ilişkisi (Peklaj ve Levpušček, 2006; Özgüngör ve Kapıkıran, 2008; Şahin ve Çakar, 2011; Eymur ve Geban, 2011; Singh, 2011; Amrai, Motlagh, Zalani ve Parhon, 2011; Yükseloğlu ve Karagüven, 2013; Wood, Hilton ve Hicks, 2014; Çetin, 2015; Taşkesen, Yılmaz ve Taşkesen, 2016), birey-çevre uyumu, aidiyet duygusu, akademik doyum ve akademik başarı arasındaki ilişki (Duru ve Balkıs, 2015), öğretim görevlisi ve öğrenci davranışının öğrenci motivasyonu üzerindeki etkisi (Doghonadze, 2018; Sürücü ve Ünal, 2018), ikinci dil olarak İngilizce öğrenen öğrencilerin sınıf içinde motivasyonu azaltan faktörler (Lamb, 2017) incelendiği görülmektedir. Ayrıca, Husman ve Lens (1999) çalışma motivasyonunun öğrenci hedefleri tarafindan yönlendirildiğini, içsel motivasyonu zamanla azaldığını ve dışsal motivasyonun arttığını ifade etmektedir. Üniversitede öğrencilerin devam ettikleri bölümlere yönelik çalışmalarda, Ditcher (2001) mühendislik öğrencilerinin öğrenmeye ilgi duymak yerine sınav geçme motivasyonunun olduğunu, turizm bölümünde okuyan öğrencilerin "içe yansıttlmış dışsal motivasyon ve motivasyonsuzluk düzeyine iliş̧kin motivasyon düzeylerinin yüksek olduğu” (Gürdoğan, 2012), teknolojik destekli öğrenme ortamlarında içsel motivasyonun yüksek olduğu (Shroff, Vogel ve Coombes, 2008) belirtmektedir. Bazı çalışmalar okullarda uygulanan öğretim yönteminin motivasyona etkisini araştırmaktadır. Bir lisans programına kayıtlı İspanyolca dersi alan öğrencilerin sanal ortamda uygulanan programının öğrenci motivasyonuna etkisini incelemiş ve sanal dünyanın öğrenci kaygısını azaltmak ve yabancı bir dil öğrenme 
motivasyonlarını artırmak için önemli bir kaynak olabileceğini belirtmiştir (Wehner, Gump ve Downey, 2011).

$\mathrm{Bu}$ bilgiler doğrultusunda, bireyin yeterli motivasyona ve ait olma duygusuna sahip olmadı $\breve{1}$ sürece yüksek performans gösteremeyeceği söylenebilir. Pek çok meslek grubunda konu ile ilgili benzer çalışmalar olmasına rağmen sağlık bilimlerinde motivasyonun yeterince araştırılmadığg belirtilmektedir. Bununla birlikte, literatürde çocuk gelişimi bölümünde okuyan öğrencilerin ait olma duygusu ve motivasyonuna yönelik çalışmalara rastlanmamaktadır. Oysaki özel eğitim ve danışma merkezlerindeki çocuklarla, hastane de yatan çocuklarla ve okul öncesi kurumlarda küçük çocuklarla çalışacak olan bu bölüm mezunlarının ait olma ve motivasyon duygularının üst düzeyde olması, mesleğine yönelik olumlu tutumlar sergilemeleri önemlidir. Bu çalışmada çocuk gelişimi bölümü öğrencilerinin ait olma özellikleri ile yetişkin motivasyonları arasındaki ilişkiyi ortaya çıkarmayı amaçlamaktadır. Bu sayede öğrencilerin motivasyonlarına olumlu etkileyecek ve mesleklerine aidiyetlerini arttıracak çalışmaların yapılabileceği düşünülmektedir. Bu kapsamda aşağıdaki alt problem cümlelerine yanıtlar aranmıştır:

- Çocuk gelişimi bölümü lisans öğrencilerinin Ait Olma Ölçeği alt boyut puanları ile cinsiyet ve sınıf düzeyi bağımsız değişkenleri arasında anlamlı bir farklılaşma var mıdır?

- Çocuk gelişimi bölümü lisans öğrencilerinin Yetişkin Motivasyonları Ölçeği alt boyut ve toplam ölçek puanları ile cinsiyet ve sınıf düzeyi bağımsız değişkenleri arasında anlamlı bir farklılaşma var midır?

- Çocuk gelişimi bölümü lisans öğrencilerinin Ait Olma Ölçeği ve Yetişkin Motivasyonları Ölçeği alt boyut ve toplam puanları arasında anlamı bir ilişki var mıdır?

\section{Yöntem}

Bu bölümde sırası ile araştırmanın modeline, çalışma grubuna, veri toplama araçlarına ve veri toplama süreçleri ve analizine yer verilmiştir.

\section{Araştırma Modeli}

$\mathrm{Bu}$ araştırma, nicel araştırma desenlerinden birisi olan ilişkisel tarama modeline göre desenlenmiştir. Karasar (2005)'e göre ilişkisel tarama, “iki veya daha çok sayıdaki değişken arasında birlikte değiş̧im olup olmadiğını ve değişimin derecesini ve yönünü belirmeyi amaçlayan" çalışmalardır. Bu çalışmada da, "Ait Olma Ölçeği” ile "Yetişkin Motivasyonları Ölçeği” alt boyut ve toplam puanların birbirleri ile ilişkisi bakılacağından dolayı ilişkisel tarama modelidir. 


\section{Çalışma Grubu}

Araştırmada çalışma grubu kolay ulaşılabilir örnekleme ile seçilmiş olup, bir devlet üniversitesinin sağllk bilimleri fakültesinin Çocuk Gelişimi bölümüne devam eden toplam 166 lisans öğrencisidir. Çocuk gelişimi lisans öğrencilerinin demografik bilgileri Tablo 1'de verilmiştir.

Tablo 1: Araştırmaya Katılan Çocuk Gelişimi Lisans Öğrencilerinin Demografik Özellikleri

\begin{tabular}{llcc}
\hline & & $\mathbf{n}$ & $\mathbf{\%}$ \\
\hline \multirow{3}{*}{ Cinsiyet } & Kadın & 154 & 92,77 \\
\cline { 2 - 4 } & Erkek & 12 & 7,23 \\
\cline { 2 - 4 } & Toplam & 166 & 100 \\
\hline \multirow{3}{*}{ Sinıf } & 1. Sinif & 59 & 35,54 \\
\cline { 2 - 4 } & 2. Sinıf & 44 & 26,51 \\
\cline { 2 - 4 } & 3. Sinif & 63 & 37,95 \\
\cline { 2 - 4 } & Toplam & 166 & 100 \\
\hline
\end{tabular}

Tablo 1 incelendiğinde, çalışma grubuna katılan lisans öğrencilerinin \%92,77'sinin kadın, \%7,23'ünün erkek olduğu; \%37,95'inin 3. sinıf, \%35,54'ünün 1. sınıf ve \%26,51'inin ise 2. sinıf olduğu tespit edilmiştir. Araştırmada kolay örnekleme ile belirlenen üniversitenin 4. sınıf lisans öğrencisi bulunmadığg için çalışma grubuna 4. sınıf öğrencisi alınmamıştır.

\section{Veri Toplama Araçları}

Araştırmada veri toplama araçları olarak Ersanlı ve Koçyiğit (2013) tarafından geliştirilen "Ait Olma Ölçeği” ile Tolunay Ateş ve İhtiyaroğlu (2019) tarafindan geliştirilen "Yetişkin Motivasyonları Ölçeği” kullanılmıştır.

\section{Ait Olma Ölçeği}

Ait olma ölçeği ilk olarak Hagerty ve Patusky (1995) tarafindan geliştirilmiştir. Ölçek daha sonra Ersanlı ve Koçyiğit (2013) tarafından Türkçe’ye uyarlanmıştır. Bu ölçek, üniversite öğrencilerinin aileye, arkadaşlarına ve mesleğine duyduğu temel gereksinim düzeyini belirlemektedir. Beşli likert şeklinde oluşturulmuş olan bu ölçek, toplam 22 madde ve 3 alt boyuttan oluşmaktadır. Ölçek maddelerinin toplam varyansı açılama oranı ise \%58,53'tür. Ölçekte toplam 3 alt boyut vardır. Bu alt boyutlar; Aile Grubuna Aidiyet, Arkadaş Grubuna Aidiyet ve Mesleğe Aidiyet'tir. Ölçek güvenirlikleri hesaplandığında, cronbach alpha değerleri Aile Grubuna Aidiyet alt boyutunun .88, Arkadaş Grubuna Aidiyet .88 ve Mesleğe Aidiyet alt boyutunun ise .89 bulunmuştur. Bu araştırma kapsamında toplanan veriler üzerine tekrardan güvenirlikler hesaplanış olup, cronbach alpha değerleri Aile Grubuna Aidiyet alt boyutunda .84, Arkadaş Grubuna Aidiyet .86 ve Mesleğe Aidiyet alt boyutunun ise .80 bulunmuştur. 


\section{Yetişkin Motivasyonları Ölçeği}

Yetişkin Motivasyonları Ölçeği, yetişkin bireylerin motivasyon düzeylerini ve yönelimlerini belirlemek amacı ile Tulunay Ateş ve İhtiyaroğlu (2019) tarafından geliştirilmiştir. Ölçek beşli likert şeklinde hazırlanmıştır. Toplam 21 maddeden oluşan ölçek, toplam 2 alt boyuttan oluşmaktadır. Bu alt boyutlar; içsel motivasyon ve dışsal motivasyondur. Ölçek toplam puanla da hesaplanabilmektedir. Ölçek maddelerinin toplam varyansı açıklama oranı ise $\% 47,95$ 'tir. Ölçek güvenirlikleri hesaplandığında, cronbach alpha değerleri içsel motivasyon için .92, dışsal motivasyon için .82 ve ölçek geneli için ise .94 olarak hesaplanmıştır. Bu araştırma kapsamında toplanan veriler üzerine tekrardan güvenirlikler hesaplanış olup, cronbach alpha değerleri içsel motivasyon alt boyutunda .92, dişsal motivasyon alt boyutunda .88 ve ölçek toplam puanında ise .89 bulunmuştur.

\section{Veri Toplama ve Analizi}

Veriler 2018-2019 eğitim öğretim yılı güz yarıyılında toplanmıştır. Kolay ulaşılabilir örnekleme yöntemine göre bir devlet üniversitesindeki çocuk gelişimi bölümü çalışma için belirlenmiştir. Çalışma için gerekli izinler alındıktan sonra lisans öğrencilerine çalışmanın amacı detaylı olarak anlatılmıştır. Çalışmaya gönüllü katılan lisans öğrencilerine ders aralarında ölçekler verilmiş ve aynı gün ölçekler toplanmıştır.

Verilerin basıklık çarpıklık hesaplamaları yapılmıştır. George ve Mallery (2010)'e göre verilerin basıklık ve çarpıklık değerleri +2 ile -2 arasında bir değer ise normal dağılım gösterdiğini ifade eder. $\mathrm{Bu}$ çalışma için yapılan analizler sonucu, basıklık ve çarpıklık değerlerinin +2 ile -2 değeri arasında olmadığı tespit edilmiştir. Bu nedenle veriler normal dağılım göstermemektedir. Bu nedenle yapılacak olan istatistiki işlemlerde nonparametrik testler kullanılmıştır. Cinsiyet bağımsız değişkeni ile yapılacak işlemlerde Mann Whitney U testi, sınıf değişkeninde ise Kruskall Wallis H testi kullanılmıştır. İki değer arasındaki ilişkiyi bulmak içinde Spearman Korelasyon Analizinden yararlanılmıştır.

\section{Bulgular}

Araştırmanın ilk alt problemi doğrultusunda çocuk gelişimi lisans öğrencilerinin Ait Olma Ölçeği “Arkadaş Grubu”, "Aile” ve "Meslek” alt boyut puanları ile cinsiyet bağımsız değişkeni arasında anlamlı bir farklılaşmanın olup olmadığının tespiti için Mann Whitney U Testi uygulanmıştır. Analiz sonuçları Tablo 2'de verilmiştir.

Tablo 2: Cinsiyet İle Ait Olma Ölçeği Puanları Arasındaki Mann Whitney U Testi Sonuçları

\begin{tabular}{llllllllll}
\hline Ait Olma Ölçeği & Gruplar & $\mathbf{n}$ & $\bar{x}$ & Ss & SO & ST & U & Z & \multicolumn{1}{l}{ p } \\
\hline \multirow{2}{*}{ Arkadaş Grubu } & Kadın & 154 & 28,695 & 5,637 & 86,88 & 13380,0 & 403,0 & $-3,260$ &, $001^{* *}$ \\
& Erkek & 12 & 22,500 & 6,346 & 40,08 & 481,0 & & & \\
\hline Aile & Kadın & 154 & 25,873 & 4,910 & 86,48 & 13317,50 & 465,5 & $-2,895$ &, $004^{* *}$
\end{tabular}




\begin{tabular}{llllllllll}
\hline & Erkek & 12 & 22,250 & 5,479 & 45,29 & 543,50 & & & \\
\hline \multirow{2}{*}{ Meslek } & Kadın & 154 & 35,525 & 7,561 & 85,86 & 13223,0 & 560,0 & $-2,273$ &, $023^{*}$ \\
& Erkek & 12 & 31,333 & 6,213 & 53,17 & 638,0 & & & \\
\hline
\end{tabular}

Tablo 2 incelendiğinde, çocuk gelişimi lisans öğrencilerinin cinsiyet değişkeni ile Ait Olma Ölçeği tüm alt boyutları arasında anlamlı bir farklılaşmaya rastlanmıştır. Tüm alt boyutlarda anlamlı farklılaşma kadın çocuk gelişimi lisans öğrencilerinin lehinedir. Bir diğer ifade ile kadın çocuk gelişimi lisans öğrencilerinin arkadaş grubu, aile ve mesleğe ait olma düzeyleri, erkek çocuk gelişimi öğrencilerine göre istatistiksel olarak yüksektir.

Çocuk gelişimi lisans öğrencilerinin Ait Olma Ölçeği “Arkadaş Grubu”, “Aile” ve "Meslek” alt boyut puanları ile sınıf bağımsız değişkeni arasında anlamlı bir farklılaşmanın olup olmadığının belirlenmesinde ise Kruskall Wallis H Testi uygulanmıştır. Analiz sonuçları Tablo 3'te verilmiştir.

Tablo 3: Sınıf İle Ait Olma Ölçeği Puanları Arasındaki Kruskal Wallis H Testi Sonuçları

\begin{tabular}{|c|c|c|c|c|c|c|c|}
\hline Ait Olma Ölçeği & Sinıf & $\mathbf{n}$ & Sira Ortalaması & Sd & $\mathrm{X} 2$ & p & Anlamlı Fark \\
\hline \multirow{3}{*}{ Arkadaş Grubu } & 1. Sinif & 59 & 86,89 & 2 & ,789 & ,789 & --- \\
\hline & 2. Sinif & 44 & 82,32 & & & & \\
\hline & 3. Sinif & 63 & 81,15 & & & & \\
\hline \multirow{3}{*}{ Aile } & 1. Sinif & 59 & 87,46 & 2 & ,893 & 640 & --- \\
\hline & 2. Sinif & 44 & 84,10 & & & & \\
\hline & 3. Sinif & 63 & 79,37 & & & & \\
\hline \multirow{3}{*}{ Meslek } & 1. Sinif & 59 & 80,14 & 2 & 1,559 & ,459 & --- \\
\hline & 2. Sinif & 44 & 91,20 & & & & \\
\hline & 3. Sinif & 63 & 81,26 & & & & \\
\hline
\end{tabular}

Tablo 3 incelendiğinde, çocuk gelişimi bölümü lisans öğrencilerinin sınıf düzeyi değişkeni ile Ait Olma Ölçeği "Arkadaş Grubu”, "Aile” ve "Meslek" alt boyut puanları arasında anlamlı bir farklılaşmaya rastlanmamıştır. Bir diğer ifade ile çocuk gelişimi lisans öğrencilerinin devam ettikleri sınıf düzeyleri ile ait olma düzeyleri arasında anlamlı bir farklılaşma bulunmamaktadır.

Araştırmanın ikinci alt problemi doğrultusunda çocuk gelişimi lisans öğrencilerinin Yetişkin Motivasyonları Ölçeği “İçsel Motivasyon”, "Dışsal Motivasyon” ve “Toplam Motivasyon” puanları ile cinsiyet bağımsız değişkeni arasında anlamlı bir farklılaşmanın olup olmadığının tespiti için Mann Whitney U Testi uygulanmıştır. Analiz sonuçları Tablo 4’te verilmiştir.

Tablo 4: Cinsiyet İle Yetişken Motivasyonları Ölçeği Arasındaki Mann Whitney U Testi Sonuçları

\begin{tabular}{llllllllll}
\hline $\begin{array}{l}\text { Yetişkin } \\
\text { Motivasyonları }\end{array}$ & Gruplar & $\mathbf{n}$ & $\bar{x}$ & Ss & SO & ST & U & Z & p \\
\hline İçsel Motivasyon & Kadın & 154 & 55,723 & 6,719 & 86,49 & 13320,0 & 463,0 & $-2,880$ &, $004 * *$ \\
& Erkek & 12 & 40,000 & 11,87 & 45,08 & 541,0 & & &, $002 * *$ \\
\hline \multirow{2}{*}{ Dışsal Motivasyon } & Kadın & 154 & 31,968 & 4,129 & 86,64 & 13343,0 & 440,0 & $-3,029$ & \\
\hline \multirow{2}{*}{ Toplam Motivasyon } & Erkek & 12 & 27,000 & 6,536 & 43,17 & 518,0 & & &, $001 *$ \\
& Kadın & 154 & 87,692 & 9,648 & 87,04 & 13403,5 & 379,5 & $-3,398$ & \\
& Erkek & 12 & 76,000 & 17,80 & 38,13 & 457,5 & & & $* \mathrm{p}<.05 * * \mathrm{p}<.01$
\end{tabular}


Tablo 4 incelendiğinde, çocuk gelişimi lisans öğrencilerinin cinsiyet değişkeni ile Yetişkin Motivasyonları Ölçeği tüm alt boyutları ile toplam puanları arasında anlamlı bir farklılaşmaya rastlanmıştır. Tüm alt boyutlarda ve toplam puanda anlamlı farklılaşma kadın çocuk gelişimi lisans öğrencilerinin lehinedir. Bir diğer ifade ile kadın çocuk gelişimi lisans öğrencilerinin içsel, dışsal ve toplam motivasyon düzeyleri, erkek çocuk gelişimi öğrencilerine göre istatistiksel olarak yüksektir.

Çocuk gelişimi lisans öğrencilerinin Yetişkin Motivasyonları Ölçeği "İçsel Motivasyon", “Dışsal Motivasyon” ve "Toplam Motivasyon” puanları ile sınıf bağımsız değişkeni arasında anlamlı bir farklılaşmanın olup olmadığının belirlenmesinde ise Kruskall Wallis H Testi uygulanmıştır. Analiz sonuçları Tablo 5'te verilmiştir.

Tablo 5: Sınıf İle Yetişken Motivasyonları Ölçeği Puanları Arasındaki Kruskal Wallis H Testi Sonuçları

\begin{tabular}{|c|c|c|c|c|c|c|c|}
\hline Yetişkin Motivasyonları & Sinıf & $\mathbf{n}$ & Sira Ortalaması & Sd & $\mathrm{X2}$ & $\mathbf{p}$ & Anlamlı Fark \\
\hline \multirow{3}{*}{ İçsel Motivasyon } & 1. Sinif & 59 & 88,23 & 2 & 2,964 & 227 & --- \\
\hline & 2. Sinif & 44 & 72,90 & & & & \\
\hline & 3. Sinif & 63 & 86,48 & & & & \\
\hline \multirow{3}{*}{ Dışsal Motivasyon } & 1. Sinif & 59 & 81,99 & 2 & ,273 &, 872 & --- \\
\hline & 2. Sinif & 44 & 81,97 & & & & \\
\hline & 3. Sinif & 63 & 85,98 & & & & \\
\hline \multirow{3}{*}{ Toplam Motivasyon } & 1. Sinif & 59 & 85,58 & 2 & 1,759 & ,415 & --- \\
\hline & 2. Sinif & 44 & 75,35 & & & & \\
\hline & 3. Sinıf & 63 & 87,24 & & & & \\
\hline
\end{tabular}

Tablo 5 incelendiğinde, çocuk gelişimi bölümü lisans öğrencilerinin sınıf düzeyi değişkeni ile Yetişkin Motivasyonları Ölçeği "İçsel Motivasyon", "Dışsal Motivasyon” ve "Toplam Motivasyon" puanları arasında anlamlı bir farklılaşmaya rastlanmamıştır. Bir diğer ifade ile çocuk gelişimi lisans öğrencilerinin devam ettikleri sınıf düzeyleri ile iç ve dış motivasyon düzeyleri arasında anlamlı bir farklılaşma bulunmamaktadır.

Çocuk gelişimi lisans öğrencilerinin Ait Olma Ölçeği “Arkadaş Grubu”, “Aile” ve "Meslek” alt boyut puanları ile Yetişkin Motivasyonları Ölçeği "İçsel Motivasyon”, "Dışsal Motivasyon” ve “Toplam Motivasyon” puanları arasında anlamlı bir ilişkinin olup olmadığını belirlemek amacıyla Spearman Korelasyon Analizi uygulanmıştır. Analiz sonuçları Tablo 6'da verilmiştir.

Tablo 6: Ait Olma Ölçeği ve Yetişkin Motivasyonları Ölçeği Alt Boyut ve Toplam Puanları Arasındaki

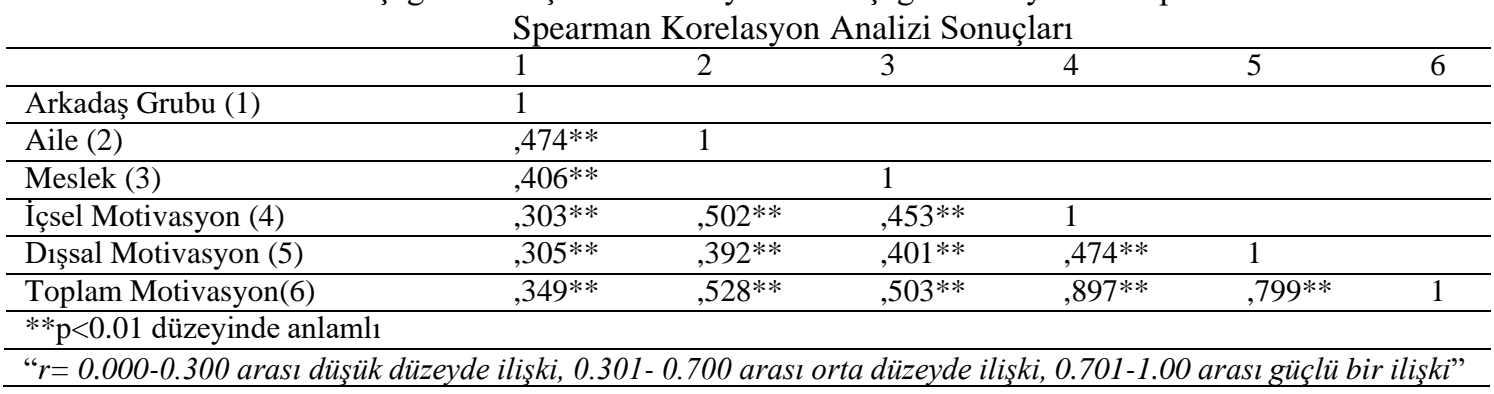


Tablo 6'ya göre, çocuk gelişimi lisans öğrencilerinin Ait Olma Ölçeği “Arkadaş Grubu”, "Aile” ve "Meslek" alt boyut puanları ile Yetişkin Motivasyonları Ölçeği "İçsel Motivasyon”, "Dışsal Motivasyon" ve "Toplam Motivasyon” puanları arasında pozitif yönlü orta düzeyde anlamlı bir ilişkinin olduğu sonucuna varılmıştır. Bir diğer ifade ile lisans öğrencilerinin arkadaş grubuna, aileye ve mesleğe ait olma düzeyi arttıkça, lisans öğrencisinin içsel, dışsal ve toplam motivasyon düzeyi artmaktadır.

\section{Tartışma ve Sonuç}

$\mathrm{Bu}$ çalışmada, çocuk gelişimi lisans öğrencilerinin ait olma düzeyleri ile yetişkin motivasyonları arasındaki ilişki incelenmiş ve elde edilen sonuçlar tartışılmıştır.

Birinci araştırma sorusuna yönelik elde edilen sonuçlar doğrultusunda, öğrencilerin cinsiyet değişkeni ile "arkadaş grubu”, "aile” ve "meslek” e ait olma alt boyutlarından aldıkları puanların, çocuk gelişimi bölümüne devam eden kadın öğrencilerinin erkek öğrencilerine göre istatistiksel olarak anlamlı olduğu, devam ettikleri sınıf düzeyleri arasında ise anlamlı bir farklılaşma olmadığı bulunmuştur. Cinsiyet değişkeninin ele alındığı benzer çalışmalar araştırmamızı destekler özelliktedir. Alçı ve Tümkaya (2019)'nın çalışmasında, “aileye ait olma” ve "mesleğe ait olma” boyutlarında üniversiteye devam eden kadın öğrencilerin, erkek öğrencilere göre daha yüksek puan aldıklarını bulmuşlardır. Yusufoğlu ve Cerev (2019)'in iktisadi ve idari bilimler fakültesinde yaptıkları benzer çalışmada, kadın katılımcıların ortama toplam aile aidiyet duygularının, erkek katılımcılara göre yüksek düzeydedir. Bir diğer çalışmada, Sürücü ve Ünal (2018) sınıf öğretmenliği erkek öğrencilerin ait olma duygularının kadın öğrencilerden düşük olduğunu belirtmişlerdir. Bilgisayar bilimi, bilim, teknoloji, mühendislik ve matematikle ilişkili bölümlerin cinsiyet eşitsizliğine sahip olduğu düşünülmektedir. Bu eşitsizliğin önemli bir nedeni, kadınların bilgisayara giriş gibi gerekli derslere kaydolmalarının ve ilgilerinin erkeklerden daha az olası olmasıdır. Cinsiyet farklılığına, başarı beklentilerinin ve fayda değerinin etkisi olsa bile, kadın öğrencilerin daha düşük aidiyet duygusuna aracılık ettiği görülmektedir (Master, Cheryan ve Meltzoff, 2016). İlgili araştırmalarda da belirtildiği gibi erkek öğrencilerin düşük puan alma nedenleri arasında, toplumumuzda genellikle kadınların erkeklere göre aileye daha bağlı olarak yetiştirilmesi, çocuk gelişiminin daha çok kadınların tercih etmesi ve toplumun kadınlara uygun bir meslek olarak algılaması ile açıklanabilir.

Araştırmamızda çocuk gelişimine devam eden öğrencilerin sınıflarına göre ait olma düzeyleri arasında farklılık görülmemiştir. Ancak sınıf değişkeni ile ait olma arasında anlamlı bir ilişki olmasa da özellikle "aile" ve "arkadaş grubu" alt boyutları puan ortalamalarının üst sınıflara doğru azaldığı, “meslek aidiyeti”nden aldıkları puan ortalamalarında farklılık olmadığı görülmektedir. Bunun nedenleri arasında özellikle farklı şehirlerden ailelerinden ayrılıp gelen öğrenciler, okula başladıklarında aile ile iletişimleri, ilişkilerini devam ettirirken, üst sınıflara geçtikçe öğrencilerin aileden uzaklaşmaları daha çok okulla ilgili çalışmalara ağırlık vermeleri nedeni ile iletişimin azaldığı ve ait olma duygusunu 
etkilediği düşünülmektedir. Aynı şekilde arkadaş grubu boyutundaki puanlarda azalma ise ilk yıl öğrencilerin arkadaş grupları ile vakit geçirebildikleri, daha sonraki sınıflarda alan uygulamaları ve staja yönelik çalışmaların artması ile birlikte arkadaş grupları ile vakit geçirememekte bununda arkadaş grubu ait olma boyutu puanlarını etkilediği düşünülmektedir. Araştırmamızın sonucunu destekleyen araştırmalara rastlanmamıştır. Literatür incelendiğinde, farklı sonuçlar karşımıza çıkmaktadır. Sınıf değişkeni ile "ait olma" ilişkisine yönelik yapılan bir çalışmada, üniversite son sınıf öğrencilerinin "mesleğe ait olma" düzeylerinin araştırmaya alınan diğer sınıflara oranla daha yüksek çıktığı sonucuna ulaşılmıştır (Ersanlı ve Koçyiğit, 2013). Bir diğer çalışmada, sınıf öğretmenliği öğrencilerinin son sınıfta "mesleğe ait olma düzey" puanlarının 1., 2. ve 3. sınıf öğrencilerinin puanlarına oranla anlamlı bir şekilde yüksek çıktığı tespit edilmiştir. Bu bulgunun temel nedeni araştırmada, öğrencinin daha önce yaşamış olduğu ortamı ve evi yeni bırakıp yeni bir çevreye gelmesi ve bu durumdan dolayı öğrencinin yabancılık çekmesi olarak açıklanmıştır. Yıılar ilerledikçe ortama daha fazla adapte olmakta ve yeni arkadaşlıklar sayesinde ait olma duygusunun artacağı savunulmaktadır (Alçı ve Tümkaya, 2019). Ancak bizim çalışmamızda sınıf düzeyleri arasında farklı1ık bulunmamıştır.

İkinci problem cümlesinden elde edilen sonuçlarda; kadın çocuk gelişimi lisans öğrencilerinin "içsel motivasyon”, “dışsal motivasyon” ve "toplam motivasyon” düzeyleri, erkek çocuk gelişimi öğrencilerine göre istatistiksel olarak yüksek olduğu saptanmıştır. Benzer konuda yapılan çalışmaların bulguları ile bu çalışmanın bu bulgusu paralellik göstermektedir. Birçok çalışma bulgusu incelendiğinde, kadınların erkeklere oranla daha yüksek bir motivasyon düzeyine sahip olduğu görülmektedir (Alemdağ, Erman ve Y1lmaz, 2014; Erdem ve Gözel, 2014; Eymur ve Geban, 2011; S1cak ve Başören, 2015; Taşkesen, Yılmaz ve Taşkesen, 2016). Bir diğer çalışmada ise, Küçükosmanoğlu (2015) tarafından müzik öğretmenliği lisans öğrencileri ile gerçekleştirilmiş ve bazı alanlarda erkek bazı alanlarda da kadın lisans öğrencilerinin motivasyon düzeylerinde anlamlı farklılaşmalar gösterdiği sonucuna varılmıştır. Erkek lisans öğrencilerin kadın lisans öğrencilerine göre "bilmeye yönelik içsel motivasyon", "uyarım yaşamaya yönelik içsel motivasyon" ve "içe yansıyan dı̧şal motivasyon" düzey puanlarında daha yüksek puana sahip iken, kadın lisans öğrencileri ise "dışsal motivasyon-dış düzenleme" düzey puanlarının erkek lisans öğrencilerinden daha yüksek olduğu sonucuna ulaşılmıştır. Bazı araştırma bulguları incelendiğinde ise cinsiyet ile akademi motivasyon düzeyleri arasında anlamlı bir farklılaşmaya rastlanmamaktadır (Gürşimşek, 2002; Gençay ve Gençay 2007; Arıŏul, 2009; Şahin ve Çakar, 2011; Demir ve Arı, 2013; Makhabbat, Çoklar ve Gündüz, 2018). Bazı çalışmalar ise cinsiyet ile içsel motivasyon karşılaştırılmış (Eymur ve Geban, 2011) ve anlamlı fark olmadığı sonucunu bulmuşlardır. Yükseloğlu ve Karagüven (2013) tarafından mesleki ve teknik okul öğrencileri ile yapılan çalışmada, erkek öğrencilerin akademik motivasyonlarının kadın öğrencilerden daha yüksek olduğunu saptamışlardır. Bu araştırmaya benzer sonuçlara ulaşan araştırmalarda, kadın öğrencilerin erkek 
öğrencilere göre motivasyon düzeylerinin daha yüksek olduğu söylenebilir. Bu durum meslekten ya da bölümün özelliğinden de kaynaklı olabilir. Teknik alanlarda okuyan kadın öğrencilerin motivasyonları daha düşükken, öğretmenlik gibi daha çok kadın öğrencilerin tercih ettiği bölümlerde kadın öğrencilerin motivasyon düzeyleri yüksek olduğu düşünülmektedir.

Çocuk gelişimi bölümü lisans öğrencilerinin devam ettikleri sınıf düzeyleri ile iç ve dış motivasyon düzeyleri arasında anlamlı bir farklılaşma bulunmamaktadır. İç ve dış motivasyon düzeylerinde farklılığın olmamasının sebebi olarak öğrencilerin; çocuk gelişimi bölümünü araştırarak geldikleri, mesleğe yönelik bilgi edindikleri dolayısıyla ilerideki mesleğini içselleştirdikleri şeklinde açıklanabilir. Benzer bir çalışmada, Eğmir, Ödemiş, Bayar, Bayar ve Kayır (2013) ile Gürşimşek (2002)'in yaptıkları çalışmadır. Bu çalışmalarda da akademik güdüleme ile yaş arasında anlamlı bir ilişkinin olmadığı bulunmuştur. Bu çalışmadan farklı olarak, Eymur ve Geban (2011) yaptıkları çalışmada, birinci sınıf öğrencilerinde yüksek motivasyon puanları gözlenmiştir. Bu bulgu doğrultusunda araştırmacılar, birinci sınıf öğrencilerinin öğrenimlerine başlarken daha fazla dişsal motivasyonla başladığını savunmuşlardır. Ayrıca sınıf düzeyi arttıkça dışsal motivasyon yerini içsel motivasyona bıraktığı düşüncesini belirtmişlerdir. Küçükosmanoğlu (2015)'nun yaptığ1 çalışma sonucunda son sınıf lisans öğrencilerinin hem içsel hem de dişsal motivasyon puanlarının diğer sınıf düzeylerine göre daha düşük olduğu bulgusuna ulaşmıştır. Alemdağ, Erman ve Yılmaz (2014) çalışmasında da benzer bir bulguya rastlanmış ve sınıf düzeylerine göre birinci ve dördüncü sınıfta öğrenim gören katılımcıların lehine olduğu sonucuna ulaşılmışır. Alanyazın incelendiğinde, öğrencilerin öğrenim görmüş olduğu sınıf düzeyi arttıkça motivasyon düzey puanlarının da arttığını gösterir çalı̧̧malara rastlanmaktadır (Gürşimşek, 2002; Gençay ve Gençay, 2007; Eymur ve Geban, 2011; Demir ve Arı, 2013; Uyulgan ve Akkuzu, 2014; Taşkesen, Yılmaz ve Taşkesen, 2016).

Araştırmanın üçüncü problemine yönelik sonuçlar incelendiğinde, çocuk gelişimi lisans öğrencilerinin ait olma ölçeği "arkadaş grubu”, "aile" ve "meslek" alt boyutlarından aldıkları puan arttıkça, "içsel motivasyon", "dlşsal motivasyon" ve toplam motivasyon düzeyi de artmaktadır. İlgili literatür de bu bulguları desteklemektedir. Özellikle, sosyal bağlamlar, motivasyon, kişisel gelişim ve kişilerarası farklı1ıkları etkiler, bu da insanların bazı durumlarda, alanlarda ve kültürlerde diğerlerine göre daha fazla kendi kendini motive, enerjik ve entegre olmalarına neden olur (Ryan ve Deci, 2000). Bu sosyal bağlamlardan biri olan okul ortamı öğrencilerin öğrenme yaşamındaki deneyimleri ile aidiyet duyguları doğrudan ilişkilidir (Osterman, 2010). Fredericks, Blumenfeld ve Paris (2004), okula ait olma hissi ile okula karşı duyulan hoşlanma ve okulda uygulanan etkinliklere katılma durumu arasında anlamlı bir ilişki olduğunu savunmaktadır. Uwah, McMahon ve Furlow (2008) ise okula aidiyet duygusu ile farklı eğitim çıktıları arasında bir ilişki olduğunu savunmaktadır. Adelabu (2007) ve Israelashvili (1997)'nin yaptığı çalışmada, öğrencilerin okula aidiyet duygusu ile gelecek beklentileri arasında 
anlamlı bir ilişkinin olup olmadığı incelenmiştir. Çalışma sonucunda araştırmaya katılan öğrencilerin okula aidiyet duyguları ile gelecek beklentileri arasında yüksek düzeyde anlamlı bir ilişkinin olduğu sonucuna ulaşılmıştır. Bir diğer ifade ile okula aidiyet duygusu olumlu olan öğrencilerin geleceğe dair daha olumlu bir akış açısına sahip olduğu saptanmıştır.

Kendini daha büyük grubun parçası olduğunu hissetmek için sık ve sürekli ilişkisel etkileşimlere ihtiyaç duyulmaktadır. Bu davranışı sürmek için ise yeterli motivasyon gereklidir (Baumeister ve Leary, 1995). Lisans öğrencilerin bilgiyi içselleştirmemiş olması, yetersiz katılım, erteleme davranış eğilimi, düşük notlar, düşük bilgi kalitesi, sorumluluğu yerine getirememe, düşük motivasyona neden olmaktadır (Doghonadze, 2018). Bu bilgiler doğrultusunda çocuk gelişimi lisans öğrencilerinin ait olma ve motivasyonlarının yüksek olması üniversiteye, bölüme mesleği ve üniversiteyi tanıyarak geldikleri, mesleğin gerekliliğini yerine getirebilmek için gerek iç motivasyonları gerekse dış motivasyonlarının yüksek düzeyde olduğu söylenebilir.

$\mathrm{Bu}$ çalışmada çocuk gelişimi üniversite öğrencilerinin ait olma ve motivasyon düzeyleri araştırılmıştır. Çocuk gelişimi bölümü lisans öğrencilerinin cinsiyet değişkeni ile ait olma ve motivasyon alt boyutlarında, kadın öğrencilerinin erkek çocuk gelişimi öğrencilerine göre istatistiksel olarak yüksek olduğu, devam ettikleri sınıf düzeyleri ile ait olma ve motivasyon düzeyleri arasında ise anlamlı bir farklılaşma olmadığı bulunmuştur. Bir diğer elde edilen bulgu ise, ait olma ölçeği "arkadaş grubu", "aile" ve "meslek" alt boyutlarından aldıkları puan arttıkça, lisans öğrencisinin "içsel motivasyon", “dışsal motivasyon" ve toplam motivasyon düzeyi arttı̆̆ görülmüştür. Motivasyon ve ait olma duygusu tüm bireylerin akademik, sosyal ve psikolojik gelişimleri açısından son derece önemli olduğu yapılan çalışmalarda görülmektedir. Özellikle ait olma ihtiyacı insanların bilişleri, duyguları ve davranışları üzerinde güçlü etkileri olduğu kronik olarak karşılanmamış bu ihtiyacın bireyi etkileyebilecek birçok olumsuz sonuçlar ortaya çıkardığı görülmektedir (Gere ve MacDonald, 2010). Bunun yanı sıra kendi kendine yetkin olma, bağımsız olma (Ryan ve Deci, 2004) gibi durumları içeren içsel motivasyon ve dışsal motivasyon Dolayısıyla üniversite öğrencilerinin motivasyon ve ait olma duygusunu desteklemek onların üniversiteye devamlılığını, akademik başarılarını, olumlu meslek algısı geliştirmelerini etkileyecektir.

Yazar Katkıları: Araştırmanın her bir alt başlıklarında yazarlar çalışmaya eşit katkı sağlamıştır.

Çıkar Beyanı: Araştırmada herhangi bir kurum veya kuruluştan destek alınmamıştır. Ayrıca yazarlar arasında herhangi bir çıkar çatışması yoktur. 


\section{Kaynakça}

Adelabu, D. D. (2007). Time perspective and school membership as correlates to academic achievement among African American adolescents. Adolescence, 42(167), 525-538.

Aggarwal, J. C. (2015). Essentials of educational psychology, New Delhi: Vikas Publishing House Pvt. Ltd.

Alçı, M. ve Tümkaya, S. (2019). Öğrencilerin algıladıkları ait olma ve öğretim elemanları mesleki yeterliliklerinin akademik motivasyonlarını yordama düzeyi. Çukurova Üniversitesi Sosyal Bilimler Enstitüsü Dergisi, 28(2), 241-256.

Alemdağ, C., Erman, Ö. ve Yılmaz, A. K. (2014). Beden eğitimi öğretmeni adaylarının akademik motivasyon ve akademik öz-yeterlikleri. Spor Bilimleri Dergisi, 25(1), 23-35.

Alptekin, D. (2011). Toplumsal aidiyet ve gençlik: Üniversite gençliğinin aidiyeti üzerine sosyolojik bir araştırma (Yayınlanmamış Doktora Tezi). Selçuk Üniversitesi Sosyal Bilimler Enstitüsü, Konya.

Amrai, K., Motlagh, S. E., Zalani, H. A. ve Parhon, H. (2011). The relationship between academic motivation and academic achievement students. Procedia-Social and Behavioral Sciences, 15, 399-402.

Anderson, C. M. (2010). Linking perceptions of school belonging to academic motivation and academic achievement amongst student athletes: A comparative study between High-Revenue Student Athletes and Non-Revenue Student Athletes. University of California, California, USA. Retrieved from http://escholarship.org/uc/item/8nt3g57h\#page-1

Arıogul, S.(2009). Academic motivations of pre-service english language teachers. Hacettepe University Journal of Education, 36, 12-19.

Aydın, O., Şahin, D., Yavuz Güzel, H., Abayhan, Y., Kaya, A. G. ve Ceylan, S. (2013). Ait olma ihtiyacının ve haberdar olmanın psikolojik dışlanmaya gösterilen tepkiler üzerine etkileri. Türk Psikoloji Dergisi, 28(72), 21-31.

Baumeister, R. F. ve Leary, M. R. (1995). The need to belong: Desire for interpersonal attachments as a fundamental human motivation. Psychological Bulletin, 117, 497-529.

Booker, K. C. (2006). School belonging and the African American adolescent: What do we know and where should we go? The High School Journal, 89(4): 1-7.

Choenarom, C., Williams, R. A. ve Hagerty, B. M. (2005). The role of sense of belonging and social support on stress and depression in individuals with depression. Archives of Psychiatric Nursing, 19(1), 18-29.

Cole, M. S., Feild, H. S. ve Harris, S. G. (2004). Student learning motivation and psychological hardiness: Interactive effects on students' reactions to a management class. Academy of Management Learning \& Education, 3(1), 64-85.

Çetin, B. (2015). Predicting academic success from academic motivation and learning approaches in classroom teaching students. Contemporary Issues in Education Research, 8(3), 171-180.

Demir, M. K. ve Arı, E. (2013). Öğretmen adaylarının akademik güdülenme düzeylerinin çeşitli değişkenler açısından incelenmesi. Eğitimde Kuram ve Uygulama, 9(3), 265-279.

DeWall, C. N., Deckman, T., Pond Jr, R. S. ve Bonser, I. (2011). Belongingness as a core personality trait: how social exclusion influences social functioning and personality expression. Journal of Personality, 79(6):1281-1314. 
Ditcher, A. K. (2001) Effective teaching and learning in higher education, with particular reference to the undergraduate education of professional engineers. International Journal of Engineering Education, 17(1), 24-29.

Doghonadze, N. (2018). Undergraduate students' motivation. The fifth International Conference on Education and New Learning Technologies, Barcelona, Spain, 1-3 July, 4116-4128.

Dörnyei, Z. ve Ushioda, E. (2011) Teaching and researching motivation. 2nd Edition, Pearson, Harlow.

Duru, E., ve Balkıs, M. (2015). Birey-çevre uyumu, aidiyet duygusu, akademik doyum ve akademik başarı arasındaki ilişkilerin analizi. Ege Eğitim Dergisi, 16(1), 122-141.

Eğmir, E., Ödemiş, İ. S., Bayar, V., Bayar, A. ve Kayır, G. (2013). Lisansüstü eğitim gören ögrrencilerin akademik güdülenme düzeyleri. Sakarya Üniversitesi Eğitim Bilimleri Enstitüsü. VI. Ulusal Lisansüstü Eğitim Sempozyumu. Bildiri Kitab1, 95(6), 97-103.

Erdem, A. R. ve Gözel, E. (2014). Sınıf öğretmeni adaylarının öğretmenlik mesleğine ilişkin motivasyon düzeyleri. Akademik Sosyal Araştırmalar Dergisi, 2(1), 49-60.

Ersanl1, K. ve Koçyiğit, M. (2013). Ait Olma Ölçeği’nin psikometrik özellikleri. Turkish StudiesInternational Periodical for the Languages, Literature and History of Turkish or Turkic, 8(12), 751-764.

Eymur, G. ve Geban, Ö. (2011). Kimya öğretmeni adaylarının motivasyon ve akademik başarıları arasındaki ilişkinin incelenmesi. Eğitim ve Bilim, 36(161), 246-255.

Fagan, M.H., Neill, S. ve Wooldridge, B.R. (2008) Exploring the Intention to use Computers: An empirical investigation of the role of intrinsic motivation, extrinsic motivation and perceived ease of use in. Journal of Computer Information Systems, 31-37.

Ferguson, E. D. (2010). Adler's innovative contributions regarding the need to belong. Journal of Individual Psychology, 66(1), 1-8.

Fong Lam, U., Chen, W. W., Zhang, J. ve Liang, T. (2015). It feels good to learn where I belong: School belonging, academic emotions, and academic achievement in adolescents. School Psychology International, 36(4), 393-409.

Fredericks, J. A., Blumenfeld, P. C. ve Paris, A. H. (2004). School engagement: Potential of the concept, and state of the evidence. Review of Educational Research, 74(1), 59-109.

Gençay Ö. A. ve Gençay S. (2007). Beden eğitimi ve spor yüksekokulu öğrencilerinin öğretmenlik mesleğine ilişkin motivasyon düzeylerinin bazı değişkenler açısından incelenmesi. Selçuk Üniversitesi Sosyal Bilimler Enstitüsü Dergisi, 17(241), 241-253.

George, D. ve Mallery, P. (2010) SPSS for Windows Step by step A simple guide and reference 17.0 update. 10th Edition, Pearson, Boston.

Gere, J. ve MacDonald, G. (2010). An Update of the empirical case for the need to belong. Journal of Individual Psychology, 66, 93-115.

Goodenow, C. ve Grady, K. E. (2010). The relationship of school belonging and friends' values to academic motivation among urban adolescent students. The Journal of Experimental Education, 62(1), 60-71.

Gölpek, F. (2012). Eğitim getirilerinin özel ve sosyal açıdan incelenmesi. Afyon Kocatepe Üniversitesi İktisadi ve İdari Bilimler Fakültesi Dergisi, 14(1), 43-53.

Güçlü, A. (2019, 2 Mart). Üniversiteyi terk eden sayısı neden artıyor? Milliyet Gazetesi. Erşim adresi: https://www.milliyet.com.tr/yazarlar/abbas-guclu/universiteyi-terk-eden-sayisi-neden-artiyor$\underline{2835795}$ 
Gürdoğan, A . (2012). Meslek yüksekokulu öğrencilerinin eğitimde motivasyon düzeylerinin ölçülmesi: Ortaca meslek yüksekokulu örneği . Muğla Üniversitesi Sosyal Bilimler Enstitüsü Dergisi , 28, 149-166.

Gürşimşek, I. (2002). Öğretmen adaylarında öğrenmeye ilişkin motivasyonel inançlar ve strateji kullanımı. Muğla Üniversitesi Sosyal Bilimler Dergisi, 8, 135-155.

Hagerty, B. M. K. ve Patusky, K. (1995). Developing a measure of sense of belonging. Nursing Research, 44(1), 9-13.

Hagerty, B. M., Williams, R. A., Coyne, J. C. ve Early, M. R. (1996). Sense of belonging and indicators of social and psychological functioning. Archives of Psychiatric Nursing, 10, 235-244.

Henderson-King, D. ve Smith, M. N. (2006). Meanings of Education for University Students: Academic Motivation and Personal Values as Predictors. Social Psychology of Education, 9(2), 195-221.

Husman, J. ve Lens, W. (1999). The role of the future in student motivation. Educational Psychologist, $34(2), 113-125$.

Israelashvili, M. (1997). School adjustment, school membership, and adolescents' future expectations. Journal of Adolescence, 20, 525-535.

Keskin, R. ve Pakdemirli, M. N. (2016). Mesleki aidiyet ölçeği: bir ölçek geliştirme, geçerlilik ve güvenirlik çalışması. Journal of International Social Research, 9(43), 2580-2587.

Keskin, S. ve Seferoğlu, S. S. (2017). Öğretmen adaylarının aidiyet duyguları ve araştırma topluluğu algilarıyla ilgili bir inceleme. Mehmet Akif Ersoy Üniversitesi Eğitim Fakültesi Dergisi, 44, 90114.

Kuşat, A. (2003). Bir değerler sistemi olarak “Kimlik” duygusu ve Atatürk. Erciyes Üniversitesi Sosyal Bilimler Enstitüsü Dergisi , 1(15), 45-61.

Küçükosmanoğlu, H. O. (2015). Müzik öğretmeni adaylarının akademik motivasyon düzeylerinin belirlenmesi üzerine bir çalışma, Sanat Eğitimi Dergisi, 3(1),1-21,

Lam, U. F., Chen, W.W. ve Zhang, J. (2015). It feels good to learn where I belong: School belonging, academic emotions, and academic achievement in adolescents. School Psychology International, 36, 393-409.

Lamb, M. (2017). The motivational dimension of language teaching. Language Teaching, Surveys and Studies, 50(3), 301-346.

Leary, M. R., Kelly, K. M., Cottrell, C. A. ve Schreindorfer, L. S. (2013). Construct validity of the Need to Belong Scale: Mapping the nomological network. Journal of Personality Assessment, 95, 610 624.

Levett-Jones T, Lathlean J, Maguire J. ve McMillan M. (2011). Belongingness: a critique of the concept and implications fornursing education. Nurse Education Today, 27, 210-218.

Linnenbrink, E. A. ve Pintrich, P. R. (2002). Motivation as an enabler for academic success. School Psychology Review, 31(3), 313-327.

Makhabbat, A., Çokvar, A. N. ve Gündüz, Ş. (2018). Eğitim araştırmasına yönelik tutum ile akademik güdülenme ve akademik özyeterlik arasındaki ilişki. Kırşehir Eğitim Fakültesi Dergisi (KEFAD), 19(1), 786-801.

Master, A., Cheryan, S. ve Meltzoff, A. N. (2016). Computing whether she belongs: Stereotypes undermine girls' interest and sense of belonging in computer science. Journal of Educational Psychology, 108(3), 424-437. 
Mavili A., Kesen F. N. ve Daşbaş S. (2014). Aile Aidiyet Ölçeği: Bir ölçek geliştirme çalışması, Sosyal Politika Çalışmaları Dergisi, 33, 29-45.

Museus, S. D., Yi, V. ve Saelua, N. (2017). The impact of culturally engaging campus environments on sense of belonging, The Review of Higher Education, Johns Hopkins University Press, 40(2), 187215.

Osterman, K. F. (2000). Students' need for belonging in the school community. Review of Educational Research, 70(3), 323-367.

Özgüngör, S. ve Kapıkıran, Ş. (2008). Güzel sanatlar eğitimi öğrencilerinin öğretmenlik meslek bilgisi derslerine ilişkin motivasyon ve başarı düzeyleri. Pamukkale Üniversitesi Eğitim Fakültesi Dergisi, 23(23), 47-60.

Patall, E. A., Cooper, H. ve Robinson, J. C. (2008). The effects of choice on intrinsic motivation and related outcomes: a meta-analysis of research findings. Psychological Bulletin, 134(2), 270-300.

Peklaj, C. ve Levpušček, M. P. (2006). Students' motivation and academic success in relation to the quality of individual and collaborative work during a course in educational psychology. 31st Association for Teacher Education in Europe, 147-161.

Pintrich, P.R. (2003). A motivational science perspective on the role of student motivation in learning and teaching contexts. Journal of Educational Psychology, 95, 667-686.

Pintrich, P.R. ve Schunk, D.H. (2002). Motivation in education: Theory, research, and applications. 2nd edition. Englewood Cliffs, NJ: Prentice Hall.

Ryan, R. M. ve Deci, E. L. (2000). Self-determination theory and the facilitation of intrinsic motivation, social development, and well-being. American Psychologist, 55(1), 68-78.

Ryan, R. M. ve Deci, E. L. (2004). Autonomy is no illusion: Self-determination theory and the empirical study of authenticity, awareness, and Will. In J. Greenberg, S. L. Koole, \& T. Pyszczynski (Eds.), Handbook of Experimental Existential Psychology, p. 449-479, Guilford Press.

Schoeffel, P., Wazlawick, R. S. ve Ramos, V. F. C. (2018). Motivation and engagement factors of undergraduate students in computing: A systematic mapping study. In 2018 IEEE Frontiers in Education Conference (FIE), 1-5.

Sedgwick, M. G. ve Rougeau, J. (2010). Points of tension: a qualitative descriptive study of significant events that influence undergraduate nursing students' sense of belonging. Rural and Remote Health, 10(4), 199.

Shifron, R. (2010). Adler's need to belong, as the key for mental health. Individual Psychology, 66(1), $10-31$

Shroff, R.H., Vogel, D.R. ve Coombes, J. (2008) Assessing Individual-level factors supporting student intrinsic motivation in online discussions: A qualitative study. Journal of Information Systems Education, 19, 1, 111-125.

Sıcak, A. ve Başören, M . (2015). Ortaöğretim öğrencilerinin akademik motivasyonlarının çeşitli değişkenler açısından incelenmesi (Bartın Örneği). Bartın University Journal of Faculty of Education , 4(2), 548-560.

Silvia, P.J. ve Kwapil, T.R. (2011). Aberrant asociality: How individual differences in social anhedonia illuminate the need to belong. Journal of Personality, 79, 1315-1332.

Singh, K. (2011). Study of achievementmotivation in relationtoacademic achievement of students. International Journal of Educational Planning \& Administration, 1(2). 161-171. 
Singh, S. ve Singh, A. (2011). Academic motivation among urban \& rural students: a study on traditional vs open education system in India. Turkish Online Journal of Distance Education, 12(4), 133146.

Slavin, R. E. (2013). Öğrencileri öğrenmeye motive etmek. G. Yüksel (Çev. Ed.), Eğitim Psikolojisi (ss. 284-312). Ankara: Nobel.

Spithoven, A. W., Lodder, G. M., Goossens, L., Bijttebier, P., Bastin, M., Verhagen, M. ve Scholte, R. H. (2017). Adolescents' loneliness and depression associated with friendship experiences and well-being: A person-centered approach. Journal of Youth and Adolescence, 46(2), 429-441.

Sürücü, A. ve Ünal, A. (2018). Öğrenci motivasyonunu artıran ve azaltan öğretmen davranışlarının incelenmesi. OPUS-Uluslararası Toplum Araştırmaları Dergisi, 8(14), 253-295.

Şahin H. ve Çakar E. (2011). Eğitim fakültesi öğrencilerinin öğrenme stratejileri ve akademik güdülenme düzeylerinin akademik başarılarına etkisi. Türk Eğitim Bilimleri Dergisi, 9(3), 519540.

Şeker, S. E. (2015). Motivasyon teorisi (Motivation theory). YBS Ansiklopedi, 2(1), 22-26.

Şimşek, H. (2012). Üniversite öğrencilerinin okulu bırakma eğilimleri ve nedenleri. Kuramsal Eğitimbilim Dergisi, 6(2), 242-271.

Taşkesen, O., Yılmaz, M. ve Taşkesen, S. (2016). Güzel sanatlar eğitimi bölümü öğrencilerinin bazı değişkenlere göre akademik motivasyonları ile akademik başarıları arasındaki ilişkinin incelenmesi. Erzincan Üniversitesi Eğitim Fakültesi Dergisi, 18(2), 1056-1072.

Tulunay Ateş, A. ve İhtiyaroğlu, N. (2019). Yetişkin motivasyon ölçeği: bir ölçek geliştirme çalışması. Kastamonu Education Journal, 27(2), 611-620.

Uwah, C. J., McMahon, H. G. ve Furlow, C. F. (2008). School belonging, educational aspirations, and academic self-efficacy among African American male high school students: Implications for school counselors. Professional School Counseling, 11(5), 296-305.

Uyulgan, M. A. ve Akkuzu, N. (2014). Öğretmen adaylarının akademik içsel motivasyonlarına bir bakış. Kuram ve Uygulamada Eğitim Bilimleri, 14(1), 7-32.

Wehner, A. K., Gump, A. W. ve Downey, S. (2011). The effects of second life on the motivation of undergraduate students learning a foreign language. Computer Assisted Language Learning 24(3), 277-289.

Wilson, G. (2014). Thwarted need to belong, violence, and adlerian neuroplasticity https://search.datacite.org/works/10.13140/2.1.3897.7283.

Won,S.,Wolters, C. A. ve Mueller, S.A. (2017). Sense of belonging and self-regulated Learning: Testing achievement Goals as Mediators, 402-418.

Wood, J. L., Hilton, A. ve Hicks, T. (2014). Motivational factors for academic success: perspectives of african american males in the. The National Journal of Urban Education and Practice, 7(3), 247265.

Xin Ma (2010). Sense of belonging to school: Can schools make a difference? Pages 340-349 Download citation https://doi.org/10.1080/00220670309596617

Young, A. F., Russell, A. ve Powers, J. R. (2004). The sense of belonging to a neighbourhood: Can it be meas-ured and is it related to health and well being in older women? Social Science \& Medicine, 59(12), 2627-2637.

Yukseloglu, S. M. ve Karaguven, M. H. (2013). Academic motivation levels of technical high school students. Procedia-Social and Behavioral Sciences, 106, 282-288. 
Yusufoğlu, Ö. ve Cerev, G. (2019). Gençlerde aidiyet düzeyinin akademik başarıya etkisi: Fırat Üniversitesi İktisadi ve İdari Bilimler Fakültesi örneği. Firat Üniversitesi Sosyal Bilimler Dergisi, 29 (2) , 289-302.

Yükseloğlu, S. M. ve Karagüven, M. H. (2013). Academic motivation levels of technical high school students. Procedia-Social and Behavioral Sciences, 106, 282-288. 